\title{
The potential of multicultural congregations in supporting social reconciliation
}

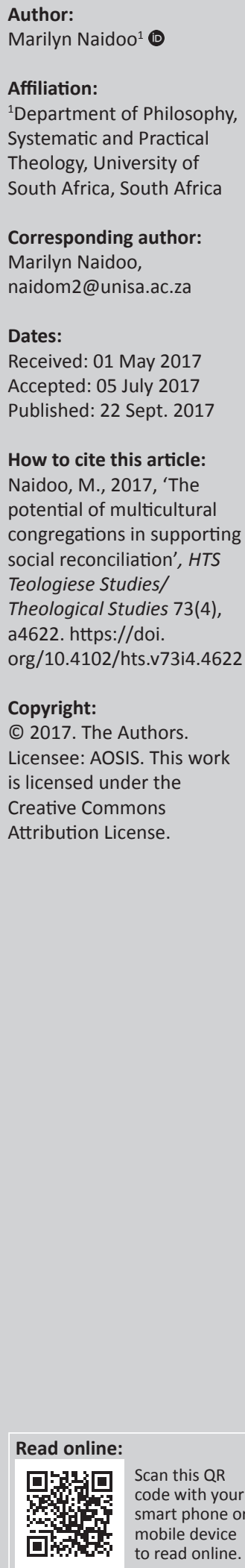

Race, ethnicity and national identity are important discussions that are unfinished ecclesial business for churches in South Africa. Churches remain mono-cultural to a large extent; a significant challenge is the fact that churches still largely reflect the social divisions of a society. Although not common in South Africa, there are, at the same time, congregations that are successful at reaching across racial and cultural divides to attract new members and build social capital. This article discusses the reconciliation potential of multicultural churches in that they are able to accommodate multiple racial groups, in a society where religious life remains overwhelmingly segregated. Racial integration is a sensitive issue that has divisive potential and churches and religions in general tend to avoid the issue. Religious communities played a critical role in the transition to democracy; what is needed now is for churches to deepen this reconciliation potential.

\section{Introduction}

Since democracy, developing and nurturing an inclusive South African identity has been a significant task for the nation-building project. However, the:

internalization of apartheid stereotypes, structures and beliefs has resulted in degrees of resistance, rigidity and low levels of adaptability of the individual or groups to the changing South African environment and its new value system. (Cross \& Naidoo 2012:228)

Jonathan Jansen calls this 'bitter knowledge', as it represents 'how people remember and enact the past' (2009:5). This is a product of 'intergenerational transmission of spoken and unspoken messages from parents, the church, school, cultural associations and the peer group' (Jansen 2009:5). These messages have not been interrupted over the period of transition despite the major changes in the formal institutions of democracy. They take place in a context of racism and where the legacy of apartheid is visible in concrete form in the shape of persistent racial inequality and segregation. Brunsdon states that 'reinforced by a growing intolerance towards others, the lack of a consolidated identity has become one of the most worrying South African realities' (2017:1).

Given the diversity of language, culture and religion in South Africa, the post-apartheid government 'sought ways to turn diversity from a potential obstacle to nationalism; a national resource seeking not uniformity but unity' (Chidester, Dexter \& Wilmot 2003:68). The pace of progress to attain nation formation and social cohesion will require further theorisation because of the persistent nature of race-based exclusions and inequalities across several indicators (MISTRA 2014:210). The question remains as to how South Africans can un-think old categories of citizenship and refine themselves as a nation in order to move beyond racial categorisation and their own political bondage (Naidoo 2015:1).

Many believe religion is a potential force for overcoming the racialised society and nearly all religions have spoken out against inequality. As religious organisations are 'mediating institutions between the private and public spheres' (Smith et al. 2007:265), they have the potential to draw people out of their private, racially segregated lives, into a social space where human interactions are more intimate than the public arena. However, the reality in far too many cases is that 'churches, the presumed agents of reconciliation are at best impotent and at worst, accomplices in strife' (Volf 1996:36). Christian organisations are structured in patriarchal and hierarchical ways with their authoritarianism. This ensures that the male prevails over the female and the clergy over the laity; hence, the roots of oppression lie deeper (Kee 2006:86). Churches, instead of being places of acceptance and love, become an arena for subtle racial tension, sexism and homophobia. This is not simply a matter of social management but one of religious values (Naidoo \& De Beer 2016:2). Thus, within religious environments, there are complex relationships 
of reproduction (of discrimination) and unequal relationships of dominance, compliance, resistance and change. People are being socialised within these kinds of Christian communities through systems of meanings; religious beliefs, communal rituals and shared traditions. The problem is that there is a failure to see how all sorts of language and behaviour reinforce what continues to be an uneven playing field (Steyn \& Conway 2010:20).

Theological uncertainties as well contribute to the ongoing racially segregated religious practice. Nico Koopman (2008) reminds us that:

The former racially separated Dutch Reformed Mission Church in South Africa and the Dutch Reformed Church in Africa unified as the Uniting Reformed Church in Southern Africa (URCSA). Although structurally unified as a multicultural and non-racial church it remains culturally and racially 'separated' mostly due to unchanged geographical demographics and systemic and institutional reasons. It is failing to construct a new theology of interracial and multiculturality despite the fact that it founded the Confession of Belhar which witnesses for authentic unity, reconciliation and justice. (p. 160)

In the Dutch Reformed tradition, 'there is a continuing struggle concerning the unity of churches' (Van Wyngaard 2014:162). Eddy van der Borght asserts that 'ecclesial structures pose a specific theological question that is an ecclesiological challenge' (2009:15). He states the theology of the church, guided by its creedal confession as being one and catholic, does not know how to account for human social diversity' (van der Borght 2009:4). Some church denominations have admitted and denounced complicity via confessional narratives and restructuring after the TRC (Van der Merwe 2003:282) but part of the challenge is that healing and reconciliation has not been sufficiently internalised or explicated in order to be sustainable. In addition churches have not fully dealt with their own apartheid legacy (Chapman \& Spong 2003:299). It is difficult for churches to take part in the transformation of society when churches itself are not transformed (Boesak 2012:106), as seen with the continuing ethnic and racial divisions within denominations or the white flight that accompanies the Africanisation of worship (Naidoo 2015).

Churches in the country continue to be segregated and where there is a racial mix in local congregations, research has indicated that external factors such as demographic changes were the majority reasons for this (Venter 2002). Internal considerations such as deliberate efforts to invite other races were quite small or actually unknown (Venter 2002). Unless forced to adapt, congregations do not change their own composition of membership deliberately. Potgieter (2016) suggests that:

These are caused by the fact that people do not really know each other and do not communicate properly because there is not enough informal personal contact. Many people simply do not have the inner motivation to try to bridge the gap because they do not like the 'uneasiness' it may cause for them. It is much easier and more natural and safer to draw back into 'known territory' and serve their own interests. (p. 1)
Interactions with people that are culturally other often leads some to withdraw and protect what is familiar. This perpetuates the stereotyping and the unwillingness to embrace the other, where cultural diversity is either absolutised or differences are minimised. The broad principle is that transformation of identities is more likely to occur when people from society's dominant social group are aware of their privileged position and willing to compromise (Christerson, Edwards \& Emerson 2005:161-162). Green, Sonn and Matsebula (2007), however, states:

that white South Africans continue to 'think white' ... believing that whiteness ought to be the norm and drawing on powerevasive strategies to deflect attention away from enduring power and privileged that accompanies domination. (p. 389)

Theological 'colour blindness' that states all cultures and races are the same leads to a reluctance to engage in dialogue with the most powerful group imposing assimilation on others (Christerson et al. 2005; Naidoo 2016). 'Meaningful conversations and changes are additionally muted in that whites typically embrace individualism and don't see themselves as raced or enjoying advantages' (McDonald 2009:5). Race is seen as an objective entity, instead of viewing it as socially constructed. This inadvertently silences the reality of race, and suppresses the idea that if these concepts are socially formed, they can equally be changed socially. There is the idea that within liturgical spaces 'it is a particular personal and communal responsibility to invite "people of other colours" into the space' (Van Wyngaard 2014:161), which then reinforces the normality of white-only spaces. In this regard, cultures of whiteness and power discourses of resistance in the church actively continue. Van Wyngaard (2014:158) reminds us that theological reflection on diversity fails to draw white Christians to reflect on their whiteness and privilege resulting in a failure to critically engage issues of 'race' in post-apartheid SA. The racism which is embedded in the church contradicts the basic tenets of the gospel, but it would seem that churches are more interested in improving their membership base and finances than in transformation (Chapman \& Spong 2003:278).

In spite of this, a developing unusual social phenomenon has been multicultural congregations. A multicultural congregation 'recognizes, embraces, utilizes and celebrates the racial, cultural, generational, gender, and other diversity represented in the community and the church' (Potgieter 2016:1). The unity of the local church is grounded on the gospel message of Christ (Eph 4:11-13). These congregations want to be a 'united Body of Christ amongst diverse cultures' and highlight that without spiritual intervention to transform people personally and as a group, behaviours are limited by cultural and human habits. So they are interesting examples of change and transformation; spiritually and socially. These churches aim to be intentionally inclusive; meaning more than just tolerance or assimilation into the dominant culture (Becker 1998). Here multiculturalism is understood not just as equal status of cultural groups but also involves examining power differentials (Stanczak 2006). This is known as critical multiculturalism (May \& Sleeter 2010:10), which refers to 
inter-cultural engagement with the 'focus on relationship building (not survival), deep connections, interactions, mutual gifting, respect, and learning from one another'. In this space, power imbalances caused by identities are attended to and people are able to see and learn from the other, which leads towards an active inclusive community. Multicultural congregations, then, can articulate powerful, discursive justifications for social reconciliation.

This article discusses the reconciliation potential of multicultural churches in that they successfully reach across cultural and racial divides to attract members in an otherwise racialised church culture. Hugo van der Merwe maintains that as there are 'racial composition, divisions, and mistrust that still exist in the churches with divisions between different congregations and branches... these internal divisions make the churches excellent laboratories for reconciliation' (2003:269). Denominations, congregations and Christians are just as needful of reconciliation and healing as any other institution in society. Van der Merwe (2003:270) asserts that 'for the church to seriously consider itself as an agent of reconciliation, it would have to firstly look at how these internal divisions can be dealt with'. This article suggests that multiracial congregations can contribute to reconciliation to the extent that it has the ability to construct and nurture an inclusive identity, which should also attend to the ability to dismantle racially aligned power structures. This article provides a brief overview of research on the multicultural congregations followed by a discussion on how inclusive congregational identity could be a possibility within our challenging South African context.

\section{The developing field}

There is a growing body of research in the United States on multicultural congregations. Michael Emerson's broader project on multiracial congregations grew out of this initial study with Christian Smith (2000), and the results of the research have been published in four significant books (Christerson et al. 2005; DeYoung et al. 2003; Emerson \& Woo 2006; Yancey 2003). These researchers addressing multiracial theory borrowed from and extend multicultural theory, to grapple with how churches manage multiple races (GarcesFoley 2007). They argue that multiracial congregations can be a means of breaking down the inequalities that Emerson and Smith (2000) identified from case studies of white evangelical congregations which emphasise biblical teaching and tend to have flexible worship styles.

Emerson and his team (Christerson et al. 2005) argue that multiracial congregations can make a distinctive contribution to racial reconciliation in the United States precisely because of their transcendent, religious nature. Because they are so emotionally and spiritually charged, appealing to transcendence and even absolute truth, they can offer powerful justifications for unity in diversity. This grounding is based on how change that takes place in voluntary civil organisations, whether religious or not, is therefore distinctive and important. Emerson and others (Christerson et al. 2005) contend that voluntary organisations with religious underpinnings may be more effective than their secular counterparts in contributing to the transformation of racial identities.

In South Africa, there is limited data on congregations and intra-congregational diversity, which makes the effort difficult. Research on multicultural churches by Venter (2002) emphasised the limits of multiracial congregations' linguistic integration. Ganiel focused on how institutional culture impacts on identity in a Charismatic church and found that the 'institutional culture of a group impacts on how identities change and the direction in which they change' (2006:555). Czeglédy (2008) in his ethnographic study revealed that a Johannesburg multicultural congregation was successful at engaging socio-economic change in post-apartheid South Africa. He highlights an evolving social dynamic whereby some religious communities have reflected the successes of the nation state, thereby exemplifying Gellner's (1997:77) observation that Protestant-type religions in general have a certain 'affinity' with nationalism. Research on mega churches in general in South Africa, such as that of Anderson (2005), focused on the lack of social integration in Pentecostal and Charismatic churches and the abuse of power by leaders (Balcomb 2004). But there are other examples in which congregations that were active in the struggle against apartheid have continued transformative, multicultural ministries in the post-apartheid period. For instance:

De Gruchy describes the work of Rondebosch United Church (Congregational and Presbyterian) in Cape Town, which has made the transition from a mono-cultural white church to a multicultural church that emphasised ministries to those who are too often forced to the edges of society. (quoted from Ganiel 2007:2)

That said, there has been limited scholarly attention on multicultural congregations and the percentage of churches in South Africa that are multicultural are not known.

In our context, 'multicultural' has become the common term used in official discourse rather than 'multiracial' as it 'deemphasizing the old racial categories, but it is not clear if "culture" has become a more meaningful category than race for most South Africans' (Ganiel 2006:557). It is also important to note that the term 'multiculturalism':

has different connotations abroad in that the dominant culture often corresponds to the culture of the majority of citizens, while the marginal cultures, which demand recognition, are often the cultures of minorities. (Lubisi 2001:2)

According to Beukman, in South Africa, on the other hand, 'while certain minority groups have been protected and promoted, the majority cultures have often been marginalised' (2000:138). Hence, the recognition of diversity and multiculturalism should be weighed up within the context of nation building. Carrim (1999) notes especially because of our apartheid history:

the challenge facing South Africa is the provision of space for people to express their multiple identities in a way that does not dislodge the quest for a South African identity. (p. 258) 
In an attempt to shape an inclusive South African identity religious leaders like Desmond Tutu (1994), with his reference to the 'rainbow nation', attempted to create new narratives grounded in Christian conceptions of forgiveness and reconciliation. Given their prior role, it might have been expected that the churches would have been major contributors to post-conflict transition in South Africa.

\section{Congregational identity}

In understanding the identity of a congregation which is a complex set of beliefs and values held by its members, one has to understand what makes a group 'us'. According to Dougherty and Huyser (2008:25), it is a socially constructed sense of 'we' that bonds people together and the stronger the sense of ' $w \mathrm{e}^{\text {' }}$ becomes in a group, the less important cultural differences are. This identity basically defines the congregation's view of itself; they are potent beliefs and values that result from the congregation's history of relating to its external environment while maintaining its own inner life (Stark \& Finke 2000). Hence, 'strong identity is capable of ameliorating internal in-group/ out-group distinctions, including those posed by race and ethnicity' (Ashforth \& Mael 1989:21).

Identity matters, '... because it is the basic cognitive mechanism that humans use to sort out themselves and their fellows, individually and collectively' (Jenkins 2014:14). According to Baker, 'social identity has three facets: cognitive (recognition of belonging to a group), evaluative (the value attached to belonging to the group), and emotional (attitudes towards insiders and outsiders)' (2012:130). Congregants create strong emotional bonds together through close faceto-face contact Sunday after Sunday and throughout weekly events. And thus congregations become important spaces of socialisation where social identities are learnt; which is an outcome of social, historical and political practices highlighting the tenacity of such identities. These individual identities are constructed, not 'given' and can perpetuate further racialisation if not deconstructed and reshaped. Christerson and Emerson (2003:164) states, 'without an analysis of the learned behaviour of oppression that perpetuates racism, these behaviours can continually be used by the dominant culture as a justification for racism'.

To move from a mono-cultural setting, which simply mirrors the societal divisions, involves 'overcoming embedded customs of social distance' (Dougherty \& Huyser 2008:40) which must be an intentional and 'requires a shift in core values and worldview' (2008:41). These types of congregations do not take shape instinctively but involves developing a shared inclusive identity that goes beyond individual racial and cultural identities (Garces-Foley 2007). Here, congregations need to teach oneness, create activities to experience oneness and encourage this unity through combined interpersonal fellowship. In this way members are compelled to invest time and energy in each other. With time an inclusive identity pervades the congregation with practices that are experiential, deliberate, interactive and relational and highlights the congregation's ability to adapt to change (DeYoung et al. 2003). A framing for this type of inclusive identity could be found in Warner's (1996) work on 'embodied ritual' (in Dougherty \& Huyser 2008):

that argues that religion plays a formative role in the maintenance of 'particularistic communities' of specific cultural groups, while simultaneously providing bridges for these particularistic communities to participate universally in a shared national context. (p. 27)

Warner states that this definition allows one to move beyond assimilation to a distinctive hybrid national culture, a mestizaje national culture. Congregations can take on a mestizaje identity, in which the cultural complexity of a country is displayed:

In these congregations, cultural differences are neither swept away nor diversity promoted over similarity; rather, religion serves as a bridge to make the rich mixture of cultures in society a part of the congregation's consciousness. (in Dougherty \& Huyser 2008:25)

For use in congregational settings, this mestizaje identity is based on a theological worldview of oneness (DeYoung et al. 2003).

However, this mestizaje identity in congregations may be challenged by the overall contested nature of the idea nation-building. Neville Alexander suggests that the concept 'rainbow nation' has been discarded because of social pathologies that South Africa is facing. He states:

There is even more confusion and an identity crisis ... by a range of conceptions about national identity and a singular ineptitude of the country's cultural and political leadership to indicate the possible trajectories of national development. (in Motala \& Vally 2011:1)

The most urgent work on identity is to distinguish between cultural captivity and nationalism. As Storey suggests, 'it comes down to a choice about which of our identities is primary - our baptism or our tribalism?' (2014:88). However our identity as Christians is in Christ and thus the church should not uncritically validate the culture around it. The church must work towards as a universal, catholic culture and play its role in building a humane society. As Alexander also wrote:

The essential point is to use this dynamic to build integration and a sense of nationhood without denying cherished practices and beliefs and without undermining diversity. It should be understood that the mainstream of a common South African culture and nation is in the process of being formed through the convergence of all present and future tributaries. (in Vally 2015:1)

Multicultural churches can play a key role in enabling Christians to play their part in the transformation of the broader society. The new interracial relationships that are created in these religious organisations can become a model of social cohesion for South African society in the future but not an uncritical kind of cohesion without deconstructing dominant constructs that continue to perpetuate inequality or injustice.

\section{Inclusive congregational formation}

Multiculturalism is new ground in South Africa and manifests a different type of community that is not yet 
mainstreamed. They are mostly evidenced amongst the Pentecostal and Charismatic tradition with many Protestant Mainline churches in urban areas working towards this integration. In the Gauteng province, for example, congregations like His People Church, Braamfontein, who have 'chosen to be together as a testimony to what God is building in South Africa', or Redemption Church whose 'approach to church is anything but traditional', both located in Johannesburg, or Hatfield Christian Church in Pretoria which values 'treating all people as important and unique as they are made in the image of God' would be examples. However, the quality of integration in these churches is not known and this would make for interesting research. According to the US research, these are often young congregations; newly founded churches and members tend to be young in terms of age (Ammerman 1997). These churches evidence the ability to be adaptable, and usually established denominations are challenged to adjust to diversity constrained by tradition (Ammerman 1997). The reason for the latter could be 'because of a desire for stability and a collective aversion to disruption' (Jun \& De la Rosa 2013:3). Daryl Smith (2009:8) submits, 'we are happy to appreciate and celebrate diversity of individuals and groups as long as, at the institutional level, things remain neutral'.

Inclusive congregations embrace integration by 'producing social networks that defy monochromatic colour-coding' (Dougherty \& Huyser 2008:27).Creating an inclusive identity requires the nurturing of a cohesive whole and is more than just bringing people of different races together. This integration depends to a large extent on the congregation's ability to nurture strong relational ties amongst members from diverse racial and cultural groups. According to Christerson et al. (2005), 'inclusive social networks are the most stable basis for multicultural congregations'. Gordon Allport's (1958) pivotal work on prejudice revealed 'the value intergroup contact can have for reducing ethnic hostilities under the right circumstances'. Close connection between members, lively worship, programming and even sharing meals will unify a group. However, given the realities of a segregated society like South Africa, creating an inclusive identity is a challenge for congregations. What are needed most are practical actions; the safe space and opportunity to hear each other's stories that could shatter racial stereotypes and beliefs that have acted as a dividing wall. Within congregations, small groups (Ammerman 1997) could facilitate this work; however, they could also serve as enclaves for those from the same cultural group (Cilliers \& Nell 2011). The latter highlights how attending to diversity may prevent integration as it can exclude others, usually on the basis of language. The worship style of the church could be problematic as it represents cultural differences and preferences within a group. Dougherty (2003:65) suggests 'that the form of contemporary, expressive worship common to charismatic denominations is a ritual capable of integrating racial groups'. In some Main-line churches, the singing of hymns using different African languages or other languages works towards being inclusive. Including new members involves using worship practices that transcend any one group (DeYoung et al. 2003). Even teaching and biblical preaching from the pulpit that places emphasis on the theological justifications for reconciliation, restitution, social justice and activism can support the development of an inclusive identity.

Deliberate efforts are needed to tackle openly the issues that divide different cultural groups. The so-called 'vernacular' service in the Methodist Church, usually conducted in an African language, intended for domestic workers, was removed to become one integrated service (Bentley 2014:151). Hadaway, Hackett and Miller (1984) 'found denominations that confronted their segregated histories were more likely to integrate black and white worshippers' (Dougherty \& Huyser 2008:26). This work is currently being conducted in some local denominations through the process of storytelling and conversations using NGOs such as the Heartlines Foundation and Phaphama Initiatives and forums such as Dialoog and Real Talk.

Denominational polity on church leadership is formative and important to note as it influences what is possible. According to Christerson et al. (2005:62), 'congregations led by clergy of diverse racial backgrounds make a strong statement about the emphasis on diversity within the fellowship'. For example, Bentley (2014:151) writing from the local Methodist Church states that as a denomination they needed to diversify the clergy to make it more representative of the local context, which involved amongst other things, implementing the cross-cultural stationing of church ministers. Yancey (2003) states:

that congregations and denominations desiring greater racial diversity will likely need to seek out new ways to develop leaders from outside the dominant culture of their organisation, for instance, looking beyond mono-racial denominational seminaries. (pp. 89-93)

Bentley (2014:151) writing from the local Methodist Church states that as a denomination they needed to diversify the clergy to make it more representative of the local context, which involved amongst other things, implementing the cross-cultural stationing of church ministers together with the integration of circuits. Thus in the Methodist context, multicultural ministry teams have been found promising (Storey 2014:86). In addition, the vision and mission of a congregation emphasise the priority of diversity within its core values. In line with Yancey and Emmerson (2003), they refer to a top-down approach to diversity driven by the pastor or the leadership as the usual way in which congregations become multiracial. Pastoral leadership was one the key reasons that congregations either adapted creatively to change or failed to do so (Carroll 2000:87).

Some external factors that impact this integration are the fact that diversity inside a congregation depends on the diversity outside its doors (Emerson \& Smith 2000). In urban and innercity areas, churches are more mixed which lead to the formation of multicultural churches in a more natural way. Another important internal factor is the denominational tradition of a congregation. According to Hadaway et al. 'denominations 
that focused on race relations earlier in their history are more likely to be diverse than denominations that did not' (1984:12). This would include the main-line churches in South Africa, like the Methodists and Anglicans who were at the forefront of the 'church struggle' (De Gruchy \& De Gruchy 2005) and have a longer history of racial integration. In terms of the growing multi-racial Pentecostal and Charismatic churches, Jeffrey Haynes and Terence Ranger state that these churches:

are inherently participatory and democratic in nature, and because they are in tune with local realities and contribute to social restructuring, they may be able to build the social capital necessary for consolidating democracy. (in Kuperus 2011:279)

These efforts of external and internal factors create a mutual relationship between the possibility of inclusive formation and the diversity found in congregations.

\section{Implications for practice}

As mentioned above, there are tremendous challenges in creating an inclusive identity made worse by the unevenness of South African society, 'continuing residential segregation and evidence that social, economic, and educational life chances still coalesce along the racial lines of the apartheid system' (Ganiel 2006:557). Research has shown that people continue to use the old racial categories to evaluate the other. For example, two congregational surveys were conducted in 2006 and 2010 amongst the membership of the Dutch Reformed Church which revealed that attendees preferred a private expression of religion with strong bonds within the congregation with little engagement with the external community (Schoeman 2015:120). Old identity categories are changing according to research conducted by Ganiel but 'this process is constrained by the power relations still embedded in its racialized society' (2006:557).

Multiracial congregations can show how they are actively working to overcome the racial stereotyping and the attached power relations, so that all are able to enjoy an equal seat and voice at the table without ignoring or de-emphasising structural realities. So can congregations move beyond what Edgell Becker (1998) calls 'personalism'? - a form of social engagement that recognises socio-political problems but does not engage with them at a socio-structural level. Ganiel (2006) states that:

For an overarching identity to become durable, it must be accompanied by structural changes that dismantle the power imbalances embedded in old racial categories. Theoretically, this deepens understanding of how the construction of identity occurs at both the individual and at the collective, structural level. (p. 560)

For true reconciliation, practice should transcend mere multicultural interaction to address the power discrepancies between cultural groups that exist within congregations. Paulo Freire (2005) believed that people could become 'culture-creators' - by actually shaping their own culture and context. The unseen forces (either individual, social or structural) that perpetuate inequality between cultural groups should be brought into conscious awareness and be addressed in the context of reconciliation.

Some see multicultural churches as the silver-bullet to racism. Some scholars like Christerson et al. (2005:28, Emerson \& Woo 2006) contend that 'racially diverse faith communities are racialised institutions that typically cater to the racial sensibilities of Whites'. Sociologist Korie Edwards (2008:49) agrees 'that most multicultural churches, in spite of the best intentions, still center white experiences and require people of color to make bigger sacrifices in adjusting themselves to white norms'. So even though these churches have many different cultural groups attending a service, they 'remain social spaces in which the White hegemony characteristic of society at large is not challenged, but rather is reproduced within the congregation' (Cobb, Perry \& Dougherty 2015:178). This issue is implicated by how race and racial categorisation itself is understood. Jennifer Harvey, in Dear White Christians, argues that the identities of 'black' and 'white' are not parallel or historically symmetrical. 'The real problem is what our differences represent, how they came to be historically, and what they mean materially and structurally still' (Harvey 2014:6). We need to acknowledge that religion was used to justify oppression; colonialism and apartheid. It must be noted that 'cultural colonisation which involves colonised minds is a deeper and long lasting form of colonial power ... more subtle and more difficult to identify, resist and transform' (Andraos 2012:10). Camacho (2016) asserts:

Whiteness is not simply a problem of one racial group mistreating another one but is about how White identity itself came into existence through constructions of systems which subjugated and categorised black people, indigenous people, and the wider world. (p. 1)

Relationships across cultures and race are critical for Christian witness in our context but are insufficient in doing away with racism. Social relations between races in our context needs to viewed within the broader context.

More than a superficial multiculturalism which boils down to demographics, we are desperately in need of Christian practice that is liberative and decolonial, that attends to structural realities and exercises long-term memory. (Camacho 2016:1)

No doubt there is a tremendous complexity in dealing with matters of racial and cultural integration especially when one considers the churches pronounced silence on the race issue and the power issues at play, but churches will have to consider how to deepen social interaction as religious communities still have a key role to play in social transformation. Research locally on multicultural churches could explore how congregations mould social definitions of we/us around racial diversity rather than mirroring the social divisions. Research could also show the connection between social practices and identity development and highlight the change process happening at a micro-level in religious communities. This could stimulate discursive discourses on the dynamics of difference and diversity with South African churches, on congregational identity and personal identity formation. 
We need resources to equip church members to assess their own passive and active contributions to disunity in the Church, evaluate the individual, social and structural factors that impede true reconciliation in congregations and develop strategic interventions to dismantle these factors and build unity. Elizabeth Peters, executive director of the South African Faith and Family Institute, states that in moving forward (quoted from Pilane 2016):

We have all been trained under the same oppression of white supremacy and patriarchy, and Christians need to acknowledge this for transformation to begin in churches. Dismantling these [notions] should be our point of entry into a decolonised Christian faith. (p. 1)

We need to challenge churches to truly transform by being visionary challengers of the status quo which requires a prophetic criticism of our society to create the possibility for an alternative reality. This involves building inclusive communities and crossing boundaries of location, denominational belonging and race. What is needed is an understanding of how different cultures reveal different aspects of God that emphasise his love and open up dialogue, contributing to greater stability.

\section{Conclusion}

Reconciliation in the churches is a public concern in a society such as South Africa. Disunity with the ranks of the church and the little progress made in ecumenical relations and a tendency of churches to concern themselves with its own survival is continually disqualifying the church for the real task of reconciliation. Faith communities had much to answer for - for like other social institutions, they were deeply implicated in both the history of oppression and the struggle to overcome it. This article showed that multicultural congregations are uniquely placed to demonstrate relatively harmonious racial relationships and practical actions for addressing inequalities. Multicultural congregations can contribute to social transformation through developing an inclusive identity; by intentional practices, internal structuring, theological discourses and constructive dialogue which could help in dismantling racially aligned power structures in community.

\section{Acknowledgements}

This research was supported by grants from the National Research Foundation and is gratefully acknowledged.

\section{Competing interests}

The author declares that she has no financial or personal relationships which may have inappropriately influenced her in writing this article.

\section{References}

Allport, G., 1958, The nature of prejudice, Doubleday, New York.

Ammerman, N.T., 1997, Congregation and community, Rutgers University Press, New Brunswick, NJ.

Anderson, A., 2005, 'New African initiated Pentecostalism and Charismatics in South Africa', Journal of Religion in Africa 35(1), 66-92. https://doi. org $/ 10.1163 / 1570066052995843$
Andraos, M.E., 2012, 'Engaging diversity in teaching religion and theology: An intercultural, de-colonial epistemic perspective', Teaching Theology and Religion 15(1), 3-15. https://doi.org/10.1111/j.1467-9647.2011.00755.x

Ashforth, B.E. \& Mael, F., 1989, 'Social identity theory and the organization', Academy of Management Review 14, 20-39.

Baker, C.A., 2012, 'Social identity theory and biblical interpretation', Biblical Theology Bulletin: Journal of Bible and Culture 42(3), 129-138.

Balcomb, A., 2004, 'From apartheid to the new dispensation: Evangelicals and the democratization of South Africa', Journal of Religion in Africa 34(1-2), 5-38. https://doi.org/10.1163/157006604323056705

Becker, P.E., 1998, 'Making inclusive communities: Congregations and the problem of race', Social Problems 45, 451-472. https://doi.org/10.2307/3097207

Bentley, W., 2014, 'Ministry as bridge building: Facilitating culturally diverse faith communities in South Africa', in R.D. Smith, W. Ackah \& A.G. Reddie (eds.), Churches, blackness and contested multiculturalism, pp. 145-156, Palgrave Churches, blackness
Macmillan, New York.

Beukman, J., 2000, Towards a commission for the promotion and protection of the rights of cultural, religious and linguistic communities. Multilingualism and government, Van Schaik, Pretoria.

Boesak, A.A., 2012, 'Theological formation in South Africa: Challenges and opportunities', in R. Venter \& F. Tolmie (eds.), Transforming theological knowledge, pp. 105-110, SunMedia, Bloemfontein.

Brunsdon, A.R., 2017, '\#MisconstruedIdentitiesMustFall collective: Identity formation in the current South African context: A practical theological perspective', HTS Theological Studies 73(2), 1-7. https://doi.org/10.4102/hts. v73i2.3822

Camacho, D.J., 2016, ‘Do multicultural churches reinforce racism?', viewed 15 April 2017, from http://www.danieljosecamacho.com/blog/2016/2/9/domulticultural-churches-reinforce-racism

Carroll, J.W., 2000, Mainline to the future: Congregations for the 21st century, Westminster John Knox Press, Louisville, KY.

Carrim, Y., 1999, 'Advancing nation building: The cultural rights commission', in G. Maharaj (ed.), Between unity and diversity, pp. 257-266, David Philip, Cape Town.

Chapman, A. \& Spong, B. (eds.), 2003, Religion and reconciliation in South Africa, Cluster Publications, Pietermaritzburg.

Chidester, D., Dexter, P. \&Wilmot, J. (eds.), 2003, What holds us together: Social cohesion in South Africa, HSRC Press, Cape Town.

Christerson, B., Edwards, K.L. \& Emerson, M.O., 2005, Against all odds: The struggle for racial integration in religious organizations, New York University Press, New York.

Christerson, B. \& Emerson, M.O., 2003, 'The costs of diversity in religious organizations: An in-depth case study', Sociology of Religion 64, 163-181. https://doi. org $/ 10.2307 / 3712369$

Cilliers, J. \& Nell, I.A., 2011, “'Within the enclave”. Profiling South African social and religious developments since 1994', Verbum et Ecclesia 32(1), 4-6.

Cobb, R.J., Perry, S.L. \& Dougherty, K.D., 2015, 'United by faith? Race/ethnicity, congregational diversity, and explanations of racial inequality', Sociology of Religion 76(2), 177-198. https://doi.org/10.1093/socrel/sru067

Cross, M. \& Naidoo, D., 2012, 'Race, diversity pedagogy: Mediated learning experience for transforming racist habitus and predispositions', Review of Education, Pedagogy, and Cultural Studies 34(5), 227-244. https://doi.org/10.1080/1071441 3.2012.735558

Czeglédy, A.P., 2008, 'A new Christianity for a new South Africa: Charismatic Christians and the post-apartheid order', Journal of Religion in Africa 38, 284-311. https:// doi.org/10.1163/157006608X323504

De Gruchy, J. \& De Gruchy, S., 2005, The Church struggle in South Africa, 25th Anniversary Edition, Fortress Press, Minneapolis, MN.

DeYoung, C.P., Emerson, M.O., Yancey, G. \& Kim, K.C., 2003, United by faith: Multiracial congregations as a response to the racial divide, Oxford University Press, New York.

Dougherty, K.D., 2003, 'How monochromatic is church membership? Racial-ethnic diversity in religious community', Sociology of Religion $64,65-85$. https://doi. org $/ 10.2307 / 3712269$

Dougherty, K.D. \& Huyser, K.R., 2008, 'Racially diverse congregations: Organizational identity and the accommodation of differences', Journal for the Scientific Study of Religion 47(1), 23-44. https://doi.org/10.1111/j.1468-5906.2008.00390.x

Edwards, K.L., 2008, The elusive dream: The power of race in interracial churches, Oxford University Press, New York.

Emerson, M.O. \& Smith, C., 2000, Divided by faith: Evangelical religion and the problem of race in America, Oxford University Press, New York.

Emerson, M.O. \& Woo, R.M., 2006, People of the dream: Multiracial congregations in the United States, Princeton University Press, Princeton, NJ.

Freire, P., 2005, Education for critical consciousness, Continuum, New York.

Ganiel, G., 2006, 'Race, religion and identity in South Africa: A case study of a charismatic congregation', Nationalism and Ethnic Politics 12(3-4), 555-576. https://doi.org/10.1080/13537110600882858

Ganiel, G., 2007, 'Religion and transformation in South Africa? Institutional and discursive change in a charismatic congregation', Transformation: Critical Perspectives on Southern Africa 63, 1-22. https://doi.org/10.1353/trn.2007.0018

Garces-Foley, K., 2007, Crossing the ethnic divide: The multiethnic church on a mission, Oxford University Press, New York. 
Gellner, E., 1997, Nationalism, Weidenfeld \& Nicolson, London.

Green, M.J., Sonn, C.C. \& Matsebula, J., 2007, 'Reviewing whiteness: Theory, research, and possibilities', South African Journal of Psychology 37(3), 389-419. https://doi. org $/ 10.1177 / 008124630703700301$

Hadaway, C.K., Hackett, D.G. \& Miller, J.F., 1984, 'The most segregated institution Correlates of interracial church participation', Review of Religious Research 25 204-219. https://doi.org/10.2307/3511119

Harvey, J., 2014, Dear white Christians: For those still longing for racial reconciliation Michigan: Eerdmans, Grand Rapids, MI.

Jansen, J.D., 2009, Knowledge in the blood: Confronting race and the apartheid past, UCT Press, Cape Town.

Jenkins, R., 2014, Social identity, 4th edn., Routledge, New York.

Jun, A. \& De la Rosa, M.L., 2013, 'Race, religion and responsibility in Christian higher education', Christian Higher Education 12, 1-4. https://doi.org/10.1080/1536375 9.2013.740320

Kee, A., 2006, The rise and demise of black theology, Ashgate, Hants, UK.

Koopman, N., 2008, 'On violence, the Belhar confession and human dignity', Dutch Reformed Theological Journal 49(3\&4), 159-166.

Kuperus, T., 2011, 'The political role and democratic contribution of churches in postapartheid South Africa', Journal of Church and State 53(2), 278-306. https://doi. org/10.1093/jcs/csr030

Lubisi, R.C., 2001, 'The meaning of multiculturalism in the South African setting and the challenge of nation building', in Proceedings of the Conference on Values, Education, and Democracy, pp. 1-8, Cape Town.

Mapungubwe Institute for Strategic Reflection (MISTRA), 2014, Nation formation and social cohesion: An enquiry into the hopes and aspirations of South African, Real African Publishers, Johannesburg.

May, S. \& Sleeter, C.E. (eds.), 2010, Critical multiculturalism: Theory and praxis, Routledge, New York.

McDonald, M.G., 2009, 'Dialogues on whiteness, leisure and (anti) racism', Journal of Leisure Research 41(1), 5-21.

Motala, E. \& Vall, S., 2011, Neville Alexander on the unresolved national question - A warning ignored, viewed 15 April 2017, from https://www.ru.ac.za/media/ rhodesuniversity/content/uhuru/images/Motala $\% 20$ and $\% 20$ Vally $\% 20-\% 20$ Neville $\% 2$ Alexander $\% 20$ on $\% 20$ the $\% 20$ NQ $\% 203$ june $\% 202015 \% 20 F i n a l \% 20$ (2).pdf

Naidoo, M., 2015, 'Transformative remedies towards managing diversity in South African theological education', HTS Theological Studies 71(2), 1-7. https://doi. org/10.4102/hts.v71i2.2667

Naidoo, M., 2016, 'An ethnographic study on managing diversity in two protestant theological colleges', HTS Theological Studies 74(3), 1-8. https://doi.org/10.4102/ hts.v72i1.3509

Naidoo, M. \& De Beer, S., 2016, 'Diversity: Negotiating difference in Christian communities', HTS Theological Studies 72(1), 1-8. https://doi.org/10.4102/hts.v72i1.3525

Pilane, P., 2016, 'Rivers Church pastor's bigotry exposes SA's big black Christian whitewash', viewed 15 April 2017, from https://mg.co.za/article/2016-07-01-00south-africas-big-black-christian-whitewash
Potgieter, R., 2016, 'Bicultural groups as bridges to communities', viewed 15 April 2017, from https://ironshapesiron.wordpress.com/2016/04/14/biculturalgroups-as-bridges-to-communities/

Schoeman, W.J., 2015, 'Identity and community in South African congregations', Acta Theologica 35(Suppl 22), 103-123.

Smith, D., 2009, Diversity's promise for higher education, Johns Hopkins University Press, Baltimore, MD.

Smith, T.B., Stones, C.R., Peck, C.E. \& Naidoo, A.V., 2007, 'The association of racial attitudes and spiritual beliefs in post-apartheid South Africa', Mental Health, Religion and Culture 10(3), 263-274. https://doi.org/10.1080/ 13694670600658730

Stanczak, G.C., 2006, 'Strategic ethnicity: The construction of multi-racial/multi-ethnic religious community', Ethnic and Racial Studies 29(5), 856-881. https://doi. org/10.1080/01419870600814312

Stark, R. \& Finke, R., 2000, Acts of faith: Explaining the human side of religion, University of California Press, Berkeley, CA.

Steyn, M. \& Conway, D., 2010, 'Introduction; Intersecting whiteness, interdisciplinary debates', Ethnicities 10(3), 283-291. https://doi.org/10.1177/1468796810372309

Storey, P., 2014, 'The quest for identity in the Methodist Church of Southern Africa,' in E.M. Conradie \& J. Klaasen (eds.), The Quest for Identity in so-called Mainline Churches in South Africa, pp.75-88, Sun Media, Stellenbosch.

Tutu, D., 1994, The rainbow people of God, Doubleday, New York.

Van der Borght, E.A.J.G., 2009, Sunday morning - The most segregated hour: On racial reconciliation as unfinished business for theology in South Africa and beyond, VU University Amsterdam, Amsterdam.

Van der Merwe, H., 2003, 'The role of the church in promoting reconciliation in postTRC South Africa', in A.R. Chapman \& B. Spong (eds.), Religion and reconciliation in South Africa, pp. 281-296, Templeton Foundation Press, Philadelphia, PA.

Van Wyngaard, C., 2014, "The language of "diversity" in reconstructing whiteness in the Dutch reformed church', in R.D. Smith, W. Ackah \& A.G. Reddie (eds.), Churches, blackness and contested multiculturalism, pp. 157-170, Palgrave Churches, blackness
MacMillian, New York.

Vally, S., 2015, 'The education crisis and the struggle to achieve quality public education in South Africa', Education as Change 19(2), 1-4. https://doi.org/10.10 80/16823206.2015.1085616

Venter, D., 2002, 'What is sociology that religionists should be mindful of it? The relevance of the sociology of religion for studying change in South Africa', Journal for the Study of Religion 15(2), 167-189. https://doi.org/10.4314/jsr. v15i2.6132

Volf, M., 1996, Exclusion and embrace: A theological exploration in learning and teaching, Oxford University Press, New York.

Warner, R.S., 1996, 'Religion, boundaries, and bridges', Sociology of Religion 58, 217-238. https://doi.org/10.2307/3712214

Yancey, G. \& Emerson, M., 2003, 'Integrated Sundays: An exploratory study into the formulation of multiracial churches', Sociological Focus 36, 111-126. https://doi. org/10.1080/00380237.2003.10570719

Yancey, G.A., 2003, One body, one spirit: Principles of successful multiracial churches, InterVarsity Press, Downers Grove, IL. 